\title{
Field developmental plan analysis: a case study of ' $x$ ' reservoir
}

\author{
Taiwo Oludele Osunrinde ${ }^{1} \cdot$ Iloka Chiamaka $^{1} \cdot$ Yawale Ahmad ${ }^{1}$
}

Received: 16 October 2018 / Accepted: 7 February 2019 / Published online: 1 March 2019

(c) The Author(s) 2019

\begin{abstract}
Petroleum resources remain very important to the economic growth of several nations of the world even as oil price fluctuates in the current market today. The huge cost of exploration and exploitation of these resources makes it necessary for the attainment of high level of certainty in the methods adopted for its detection, quantification, planning and production. Mapping the right reservoir, understanding of reservoir characteristics most importantly; porosity, permeability, water saturation, thickness, and area extent of the reservoir, being able to reduce the uncertainties in these properties, making the right decision on when to inject water into the reservoir, where to locate these injectors and planning of where to drill new wells are very important factors that helps to determine the hydrocarbon reserves, cost of production and the degree of exploitation success rate and thus, needs to be treated with high level of certainty. This research work was, therefore, aimed at integrating several disciplines (Geologist, Reservoir Engineer, Well Engineer and Petroleum Economist) to carry out a detailed Field Development Plan (FDP) analysis for the reservoir in other to determine its success rate and economic viability. Simulations of three different cases of waterflood were analysed to decide the optimal development strategy to be applied to the field. Economic and sensitivity analyses were also carried out for all the cases suggested for the reservoir including the natural depletion case. Waterflood case 2 had NPV of $\$ 2,163,756,338$ and the investment return of $47 \%$ and thus is recommended, since it is the best of all the cases.
\end{abstract}

Keywords Geoscientist $\cdot$ Injectors $\cdot$ Natural depletion $\cdot$ Sensitivity analysis $\cdot$ Simulations $\cdot$ Waterflooding

\section{Introduction}

Exploration and exploitation of hydrocarbon involve huge investments and risk. It is, however, the aim of the industry to devise means of producing as much hydrocarbon as possible from any discovered field to ensure maximum returns from the investments. Thus, a good development plan is vital to achieve this aim. This involves reservoir simulation studies, where the performance of the reservoir is analysed at different recovery methods and production conditions to determine the optimum method that will produce as much crude as possible. This will guide in the design of surface facilities needed to handle the produced fluids. In addition, the feasibility of the project is examined through the use of economic and uncertainty models. These models incorporate the various cash out flows and cash inflows that may be

Taiwo Oludele Osunrinde osunrinde24@gmail.com

1 Reservoir Engineering and services department, integrated Data Services Limited, Benin, Nigeria encountered in producing the field and as well the fluctuating price of oil and gas.

The simulation study is done using a model of the reservoir. The static model creates a replica of the reservoir as it is in static condition. It contains models of the reservoir structure, shape, saturation, permeability, porosity, thickness, fluid contacts, and faults. The dynamic model incorporates the flow properties and behaviour obtainable in the reservoir. This thus involves a model of the reservoir fluid and rock behaviour with pressure change, the mobility of the fluid, well model, water influx model (for a water drive reservoir) and every other activity that affect the flow of the fluid from the subsurface to the surface. It is worthy to note that there are a lot of uncertainties involve in the simulation due to the heterogeneity of the reservoir. Thus, any model designed for reservoir simulation study most recognises this to represent the reservoir as much as possible.

The objectives of the work are:

- to build a static and dynamic model of the reservoir; 
- to use the built models to analyse the reservoir in terms of primary recovery using the existing wells;

- to waterflood the reservoir either by drilling new wells or converting existing wells to an injector so as to yield maximum oil recovery;

- to carry out economics and sensitivity analysis on the presented cases, and

- to recommend the best method for field development plan.

\section{Materials, methodology and results}

The materials used in carrying this research work include the following:

- Reservoir top and base surface;

- well header information;

- SCAL porosity and permeability;

- unique well seed values; and

- petrel RE software

\section{Static model}

The major reason of constructing a fit for purpose 3D geological or static model is to capture the heterogeneity and randomness within the reservoir to make some critical decision that will help in the development of the reservoir. This model can be built using different statistical algorithms such as Sequential Gaussian Simulation, Sequential Gaussian Random Function, Kriging, Co-Kriging etc. For this research work, the Sequential Gaussian Random Function was used to populate the data.
Constructing a fit for purpose 3D geological model is based on several factors such as: understanding of the geology of the area, the Environment of Deposition within the reservoir, etc. A simple 3D grid consisting of the top, mid, and base skeletal framework of the reservoir was built from the input top and base surfaces of the reservoir. Geological cells in which the continuos (petrophysical) properties will be populated were created through this process.

A conceptual variogram analysis was developed using the major and minor range information supplied. A normal distribution was used to distribute the data. The porosity model was then built using the conceptual variogram analysis and the Sequential Gaussian Random Function to populate the data. Five various porosity realizations were modeled using a unique seed number for each porosity models.

The net-to-gross model was populated using the calculator. A relationship between the core porosity and permeability data (transformation plot) was generated based on the existing relationship between porosity and permeability. This relationship was then used to populate the permeability model using the calculator. The water saturation was also populated using the relationship provided via the calculator.

\section{Pillar gridding}

The skeletal framework of the reservoir was generated from the simple 3D grid of the input surfaces (Fig. 1). The generated skeletal framework serves as the reservoir architecture which consists of geological cells in which the reservoir properties are populated. Each of these geological cells holds a single value. The skeletal framework of the reservoir is made up of the top, mid, and base skeleton (Fig. 2a-d).

The skeleton framework of reservoir has a total grid cells of 45,000 (i.e., $25 * 36 * 50$ ) and a total grid node of 49062
Fig. 1 Top and base of the reservoir

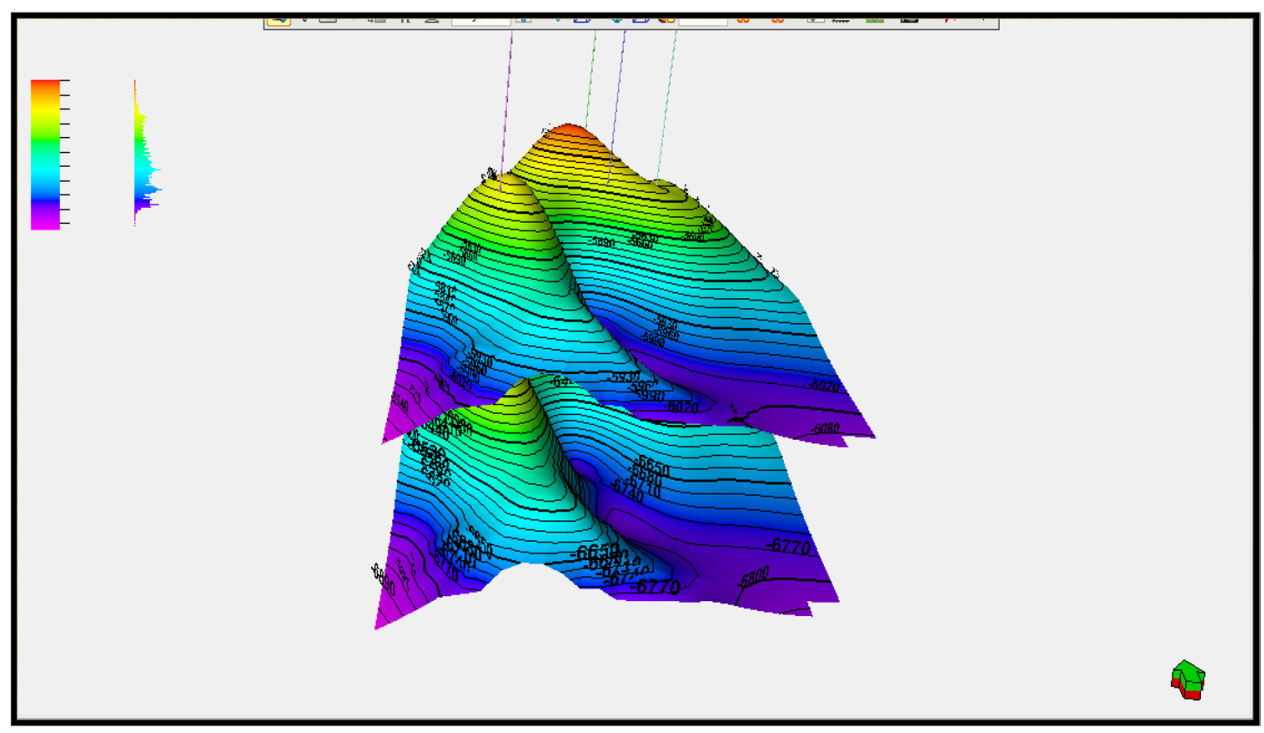


Fig. 2 a Skeletal framework of the reservoir showing the top, mid, and base skeleton. b Map view of the top skeletal framework. c Map view of the mid skeletal framework. d Map view of the base skeletal framework

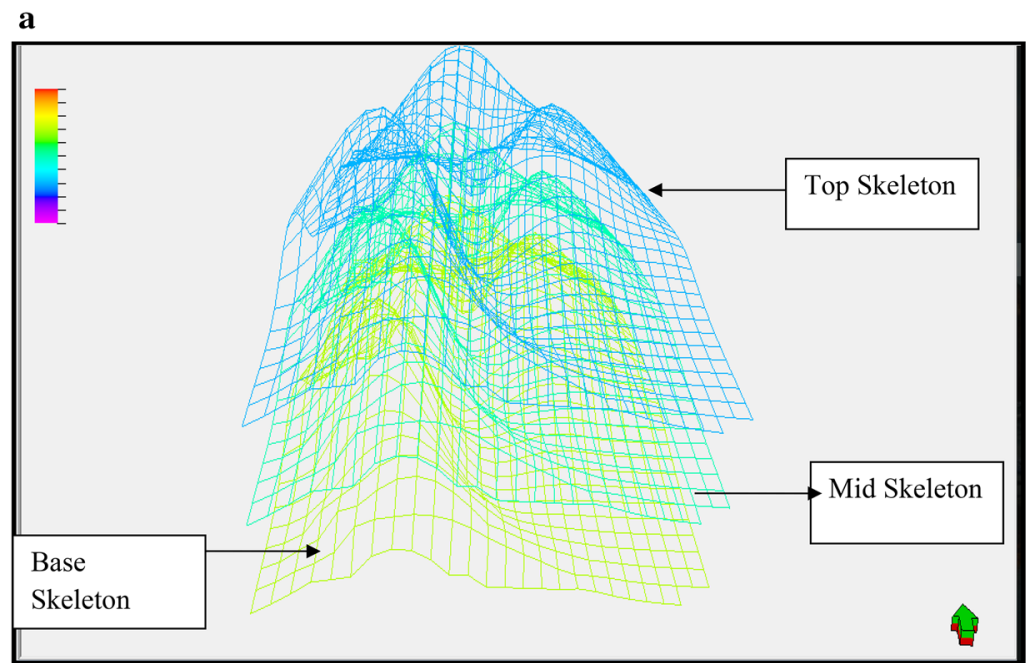

b

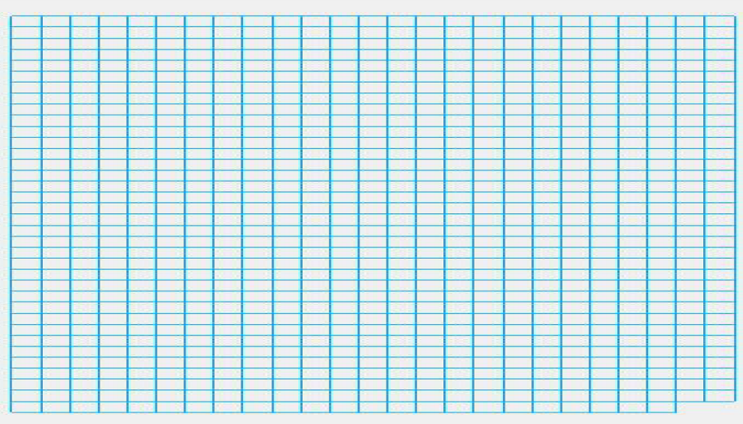

c

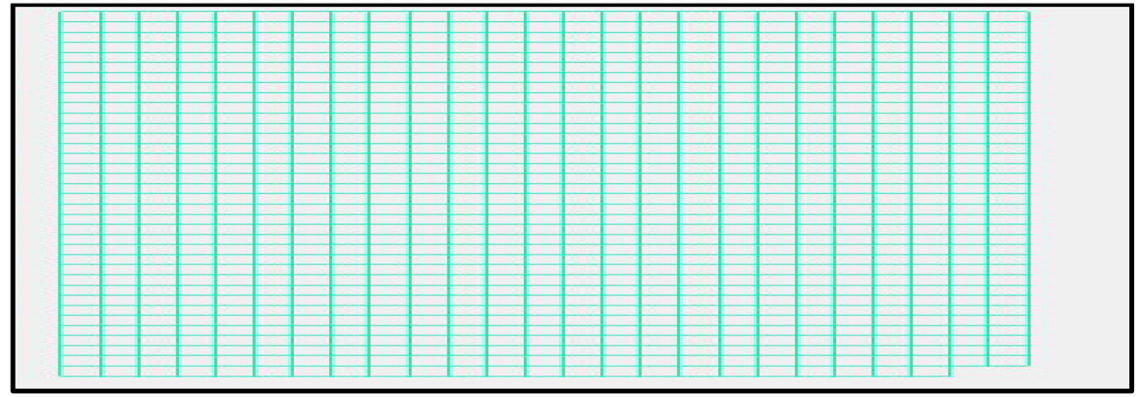

d

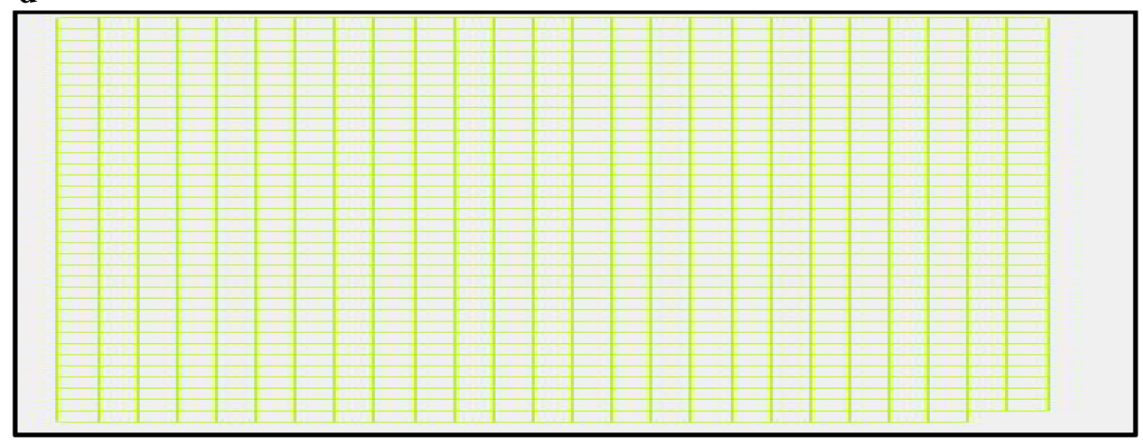


Fig. 3 3D grid statistics of the reservoir skeletal framework

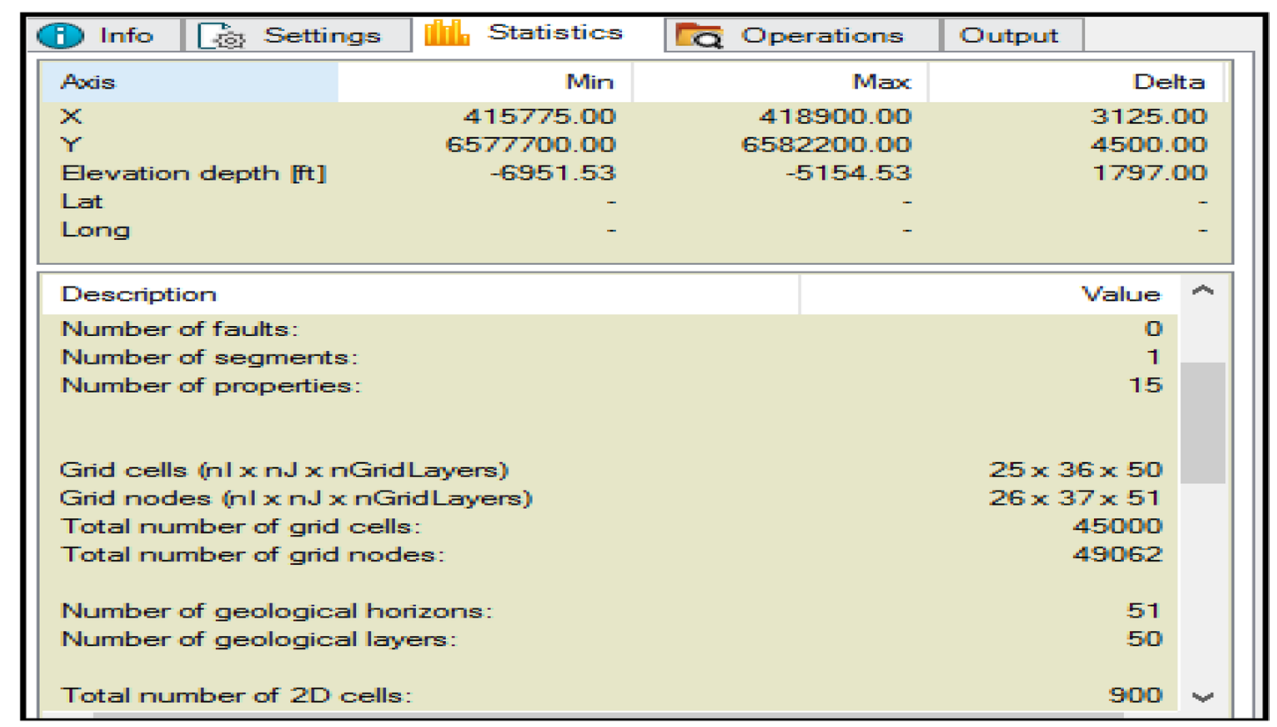

(i.e., $26 * 37 * 51)$ (Fig. 3). The above result implies that the geological heterogeneities of the reservoir will be captured with grid resolution for the construction of a fit for purpose geological model.

\section{Petrophysical model}

\section{Porosity model and net-gross model}

The total porosity gives the ratio of pore volume to the total volume of the reservoir. This was modeled using the Gaussian Random Function Simulation algorithm. A conceptual variogram analysis was used to populate the property into the reservoir grid cells. Five realizations of the total porosity model (each having its unique seed number) were generated using the same algorithm and conceptual variogram analysis.

The total porosity model with seed number 2185421 shows that the reservoir (Fig. 4a) has a minimum porosity of 0.0702 and a maximum porosity of 0.3864 . Regions with purple color indicate area with low porosity, while regions with orange color indicate area with high porosity. The model shows that the reservoir has an average total porosity (PHID) of 0.2262 . This indicates that the reservoir is very porous.

The total porosity model with seed number 2148526 shows that the reservoir (Fig. 4b) has a minimum porosity of 0.0729 and a maximum porosity of 0.3943 . Areas with purple color indicate area with low porosity, while areas with orange color indicate area with high porosity. The model shows that the reservoir has an average total porosity (PHID) of 0.2231 . This indicates that the reservoir is very porous.

The total porosity model with seed number 1987521 (Fig. 4c) gives a minimum porosity of 0.0595 and a maximum porosity of 0.3282 . Areas with purple color indicate area with low porosity, while areas with orange color indicate area with high porosity. The model shows that the reservoir has an average total porosity (PHID) of 0.2245 . This indicates that the reservoir is very porous.

The total porosity model with seed number 963584 (Fig. 4d) shows that the reservoir has a minimum porosity of 0.0689 and a maximum porosity of 0.3829 . Areas with purple color indicate area with low porosity, while areas with orange color indicate area with high porosity. The model shows that the reservoir has an average total porosity (PHID) of 0.2231 . This indicates that the reservoir is very porous.

The total porosity model with seed number 745256 (Fig. 4e) shows that the reservoir has a minimum porosity of 0.0514 and a maximum porosity of 0.3796 . Areas with purple color indicate area with low porosity, while areas with orange color indicate area with high porosity. The model shows that the reservoir has an average total porosity (PHID) of 0.2243 . This indicates that the reservoir is very porous.

In general, the five realizations of porosity generated with different unique seed number have similar average porosity value of $22 \%$.

The Net-gross model of the reservoir has an average of 0.87 . This indicates that the volume of shale within the reservoir is $13 \%$. Hence, based on the minimal amount of shale present within the reservoir, it can be concluded that the reservoir is clean. The reservoir also has an average effective porosity of $19 \%$. This suggests the pore throats are well connected.

\section{Permeability model}

The core permeability data were plotted against the core porosity data (Fig. 5a). Based on the research carried out in 
Fig. 4 a Porosity_2185421

model of the reservoir. $\mathbf{b}$

Porosity_2148526 model of the reservoir. c Porosity_1987521 model of the reservoir. $\mathbf{d}$ Porosity_963584 model of the reservoir. e Porosity_745256 model of the reservoir
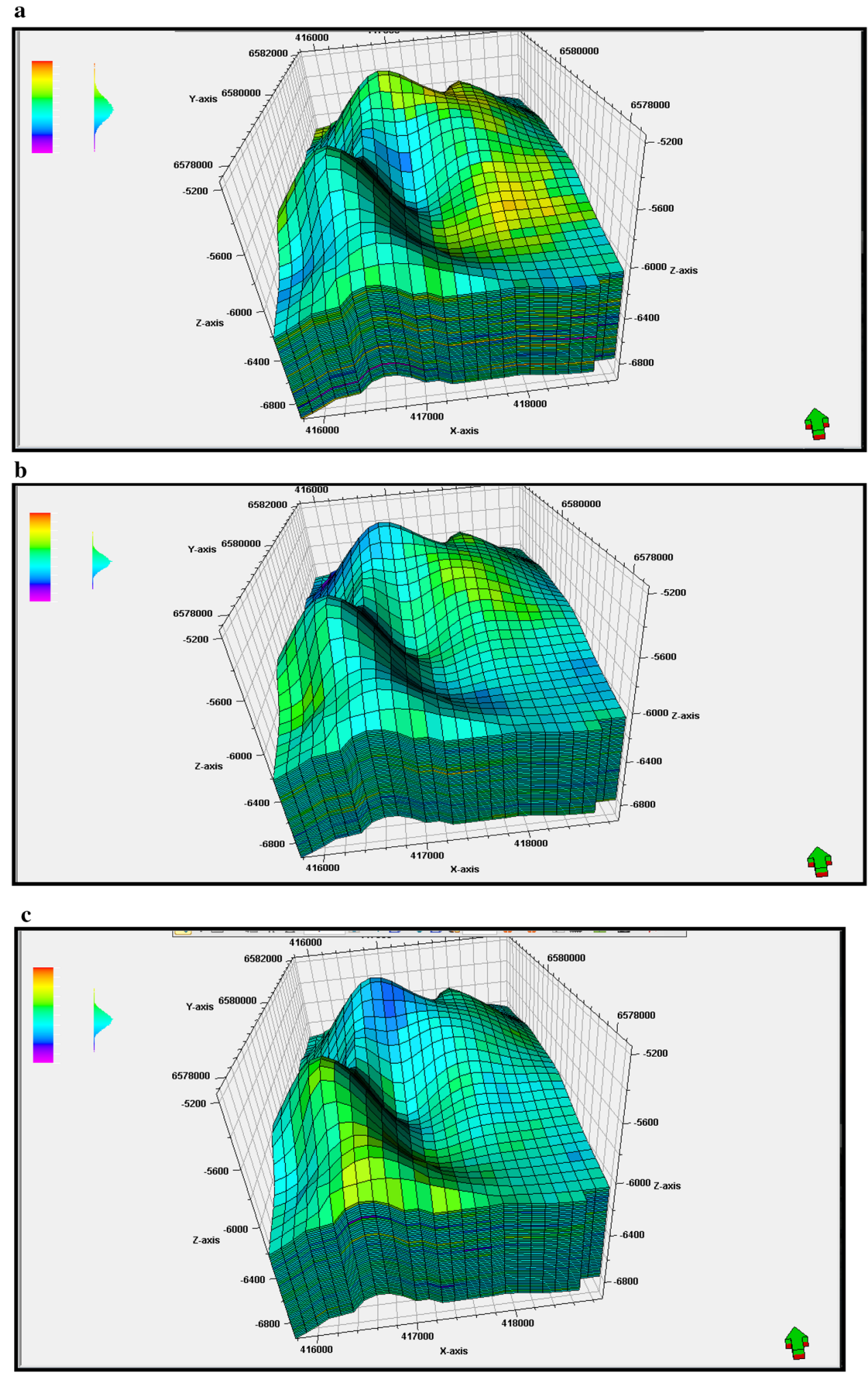
Fig. 4 (continued)

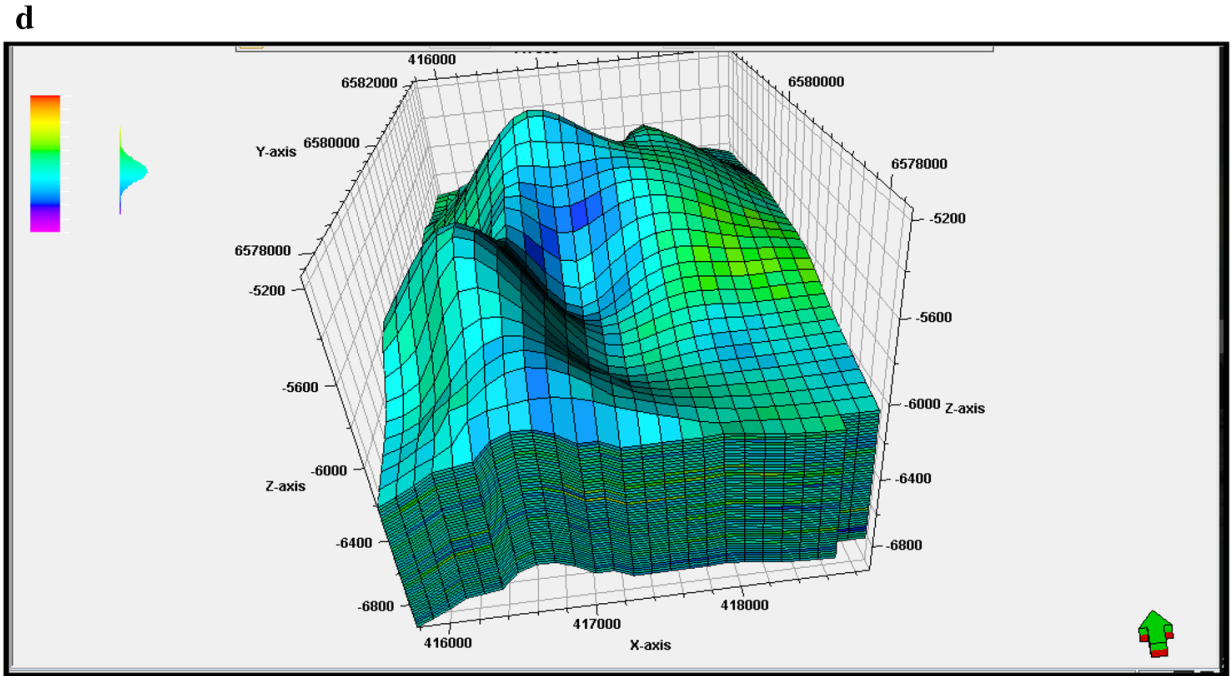

e

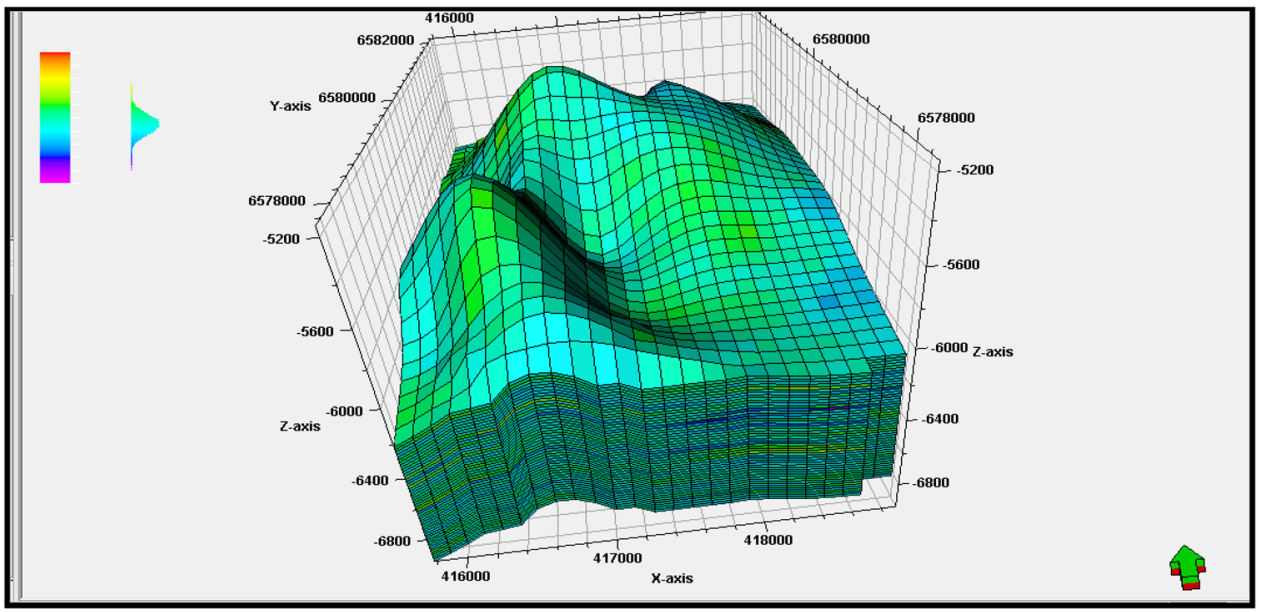

Section A, a relationship between the core permeability data and core porosity data was established. This relationship was then used to populate the permeability along the $X, Y$, and $Z$ directions. The permeability model in the $X$-direction shows that the reservoir has a minimum permeability of $1031 \mathrm{mD}$ and a maximum permeability of $36068 \mathrm{mD}$ (Fig. 5b). The average permeability within this reservoir is $10376 \mathrm{mD}$. This indicates that fluids can move properly within the pore spaces of the reservoir. The permeability model along both $\mathrm{Y}$ and $\mathrm{Z}$ direction is similar to the model along the
$X$-direction. The only difference is that the permeability model along the $Z$-direction has a mean of $1037.6 \mathrm{mD}$.

\section{Water saturation model}

The water saturation model reveals that the reservoir has a minimum water saturation of 0.17 and a maximum water saturation of 1 (Fig. 6). The average water saturation within this reservoir is 0.37 . This indicates that the reservoir is 0.69 saturated with hydrocarbon. The reservoir at this level is 


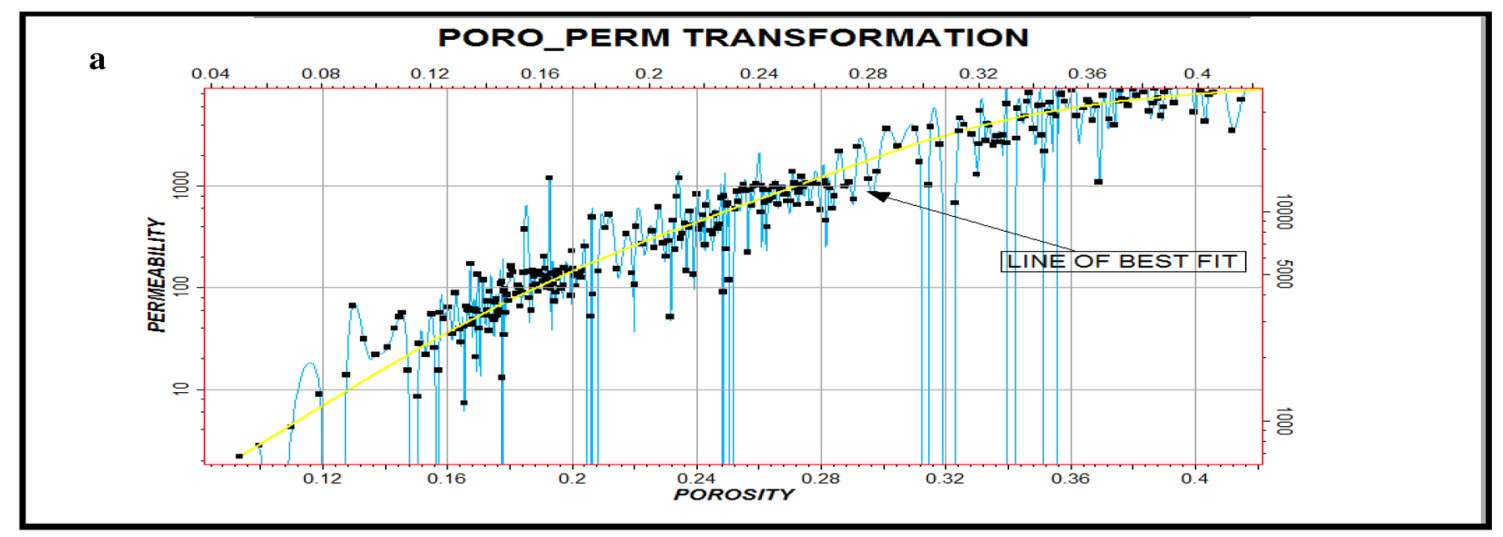

b

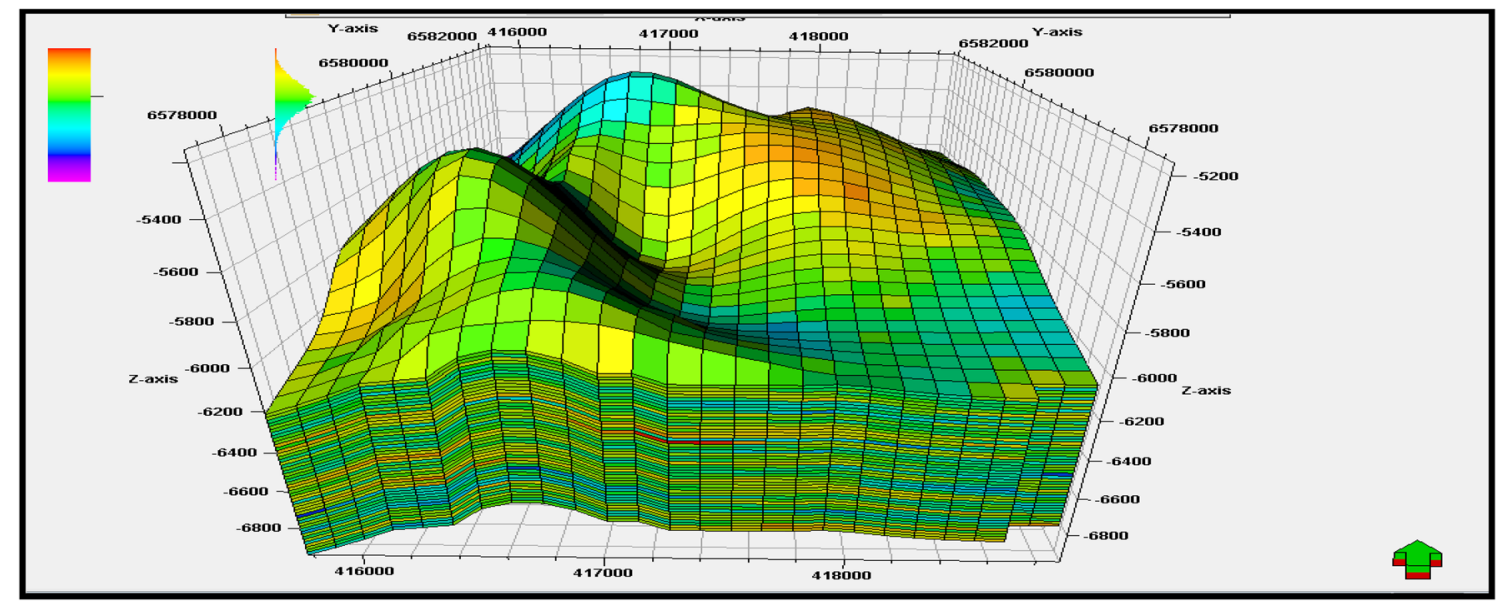

Fig. 5 a Poro-perm transformation plot. b Permeability model along the $X$ direction

Fig. 6 Water saturation model

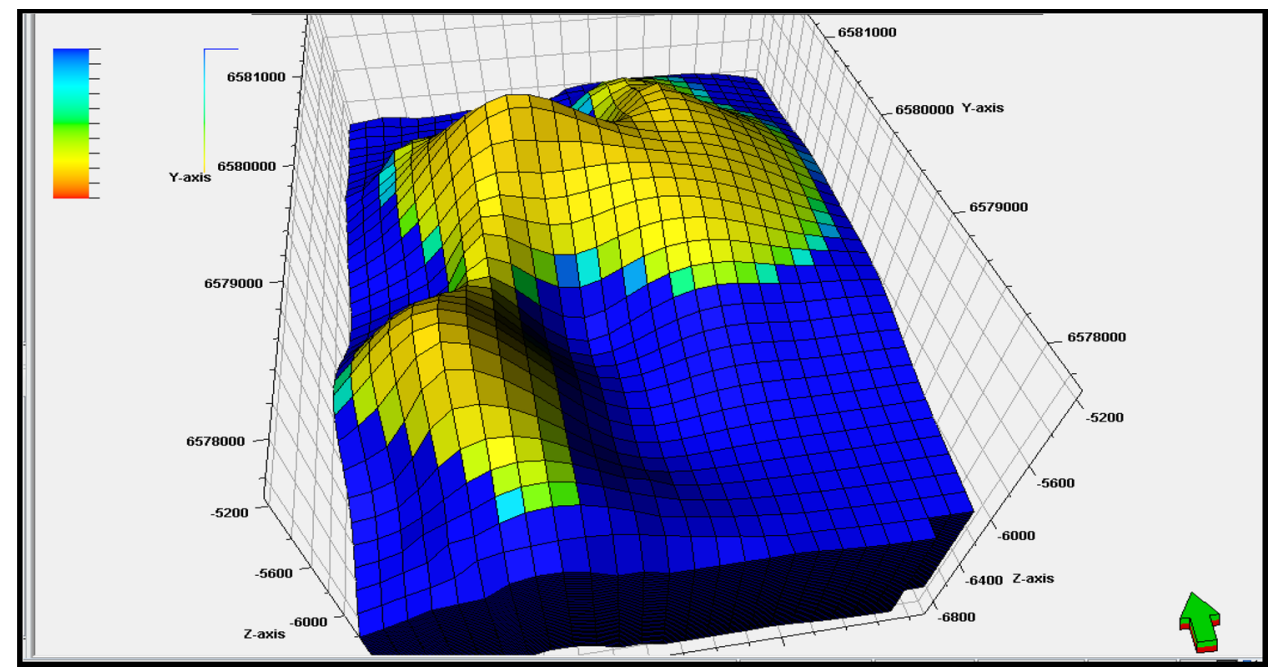


Table 1 Volumetric result for reservoir

\begin{tabular}{|c|c|c|c|c|c|c|c|c|c|c|}
\hline & $\begin{array}{l}\text { Bulk vol- } \\
\text { ume }\left(\times 10^{6}\right) \\
\mathrm{Ft}^{3}\end{array}$ & NTG & $\begin{array}{l}\text { Net volume } \\
\left(\times 10^{6}\right) \\
\mathrm{Ft}^{3}\end{array}$ & $S_{\mathrm{H}}$ & $\begin{array}{l}\text { Pore vol- } \\
\text { ume }\left(\times 10^{6}\right) \\
\text { RB }\end{array}$ & $\begin{array}{l}\text { HCPV in } \\
\text { oil }\left(\times 10^{6}\right) \\
\text { RB }\end{array}$ & $\begin{array}{l}\text { HCPV in } \\
\text { gas }\left(\times 10^{6}\right) \\
\text { RB }\end{array}$ & $\begin{array}{l}\text { STOIIP } \\
\text { (in Oil) } \\
\left(\times 10^{\wedge} 6\right) \\
\text { STB }\end{array}$ & $\begin{array}{l}\text { STOIIP } \\
\text { (in Gas } \\
\left(\times 10^{\wedge} 6\right) \\
\text { STB }\end{array}$ & $\begin{array}{l}\text { STOOIP } \\
\left(x 10^{\wedge} 6\right) \\
\text { STB }\end{array}$ \\
\hline Porosity_2185421 & 13,897 & 0.87 & 12,090 & 0.69 & 482 & 212 & 96 & 182 & 96 & 278 \\
\hline Porosity_2148526 & 13,897 & 0.87 & 12,090 & 0.69 & 485 & 213 & 96 & 183 & 96 & 280 \\
\hline Porosity_1987521 & 13,897 & 0.87 & 12,090 & 0.69 & 489 & 215 & 98 & 185 & 98 & 283 \\
\hline Porosity_963584 & 13,897 & 0.87 & 12,090 & 0.69 & 481 & 212 & 95 & 183 & 95 & 278 \\
\hline Porosity_745256 & 13,897 & 0.87 & 12,090 & 0.69 & 479 & 210 & 119 & 181 & 95 & 276 \\
\hline
\end{tabular}

saturated with both gas and oil. The model further revealed that the reservoir is saturated with $44 \%$ oil and $25 \%$ gas. The maximum water (irreducible water saturation) that the reservoir can retain without producing water is $15 \%$. This can also be referred to as the connate water saturation. The irreducible water saturation value was read from the plot of depth against $\mathrm{Sw}$ at free water level.

\section{Static volumetrics}

The volumetric of the reservoir is presented in the table below (Table 1).

\section{Dynamic model}

\section{Fluid model}

Black oil correlation was used to model the behaviour of the reservoir fluid. The correlations used are as follows: Bubble Point Pressure Vasquez \& Beggs (1980).

Solution Gas/Oil Ratio Vasquez \& Beggs (1980).

Formation Volume Factor Vasquez \& Beggs (1980).

Stock tank viscosity Kartoatmodjo \& Schmidt (1994).

Undersaturated Viscosity Beal (1946).

Effect of pressure on crude oil properties

Oil viscosity The viscosity of crude oil decreases with decreasing pressure above the reservoir bubble point pressure and increases with decreasing pressure below the reservoir bubble point pressure (Fig. 7a). This is because of the expansion of solution gas (which lightens the oil) with decreasing pressure above bubble point and liberation of the solution gas from the crude with decreasing pressure below the reservoir bubble point pressure.
Oil formation volume factor This is the ratio of volume of oil in the reservoir to its volume on the surface. It increases with decreasing pressures above bubble point, because the expanding solution gas causes increase in the reservoir oil volume, while it decreases with decreasing pressures below bubble point pressure, because the reservoir oil volume decreases with the liberation of the dissolved gas (Fig. 7b).

Solution gas oil ratio This is the measure of the volume of gas dissolve oil at a given pressure (Fig. 7c). At pressures above bubble point, all gas in the reservoir remains dissolved in oil thus solution gas oil ratio remains constant.

At pressures below bubble point pressure, the dissolved gases are liberated from the oil. Thus, solution gas oil ratio decreases, because the volume of gas dissolved in oil decreases continuously as more gas are liberate from the oil with decreasing pressure.

\section{Reservoir volume calculation}

The volume calculated after initialization without aquifer and with aquifer is $265.37 \mathrm{MMSTB}$.

\section{Production prediction}

\section{Natural Depletion}

Results from production prediction ran for a period of 20 years using the existing wells (Fig. 8) with natural depletion are shown in the tables and figures below (Table 2).

It can be observed that the reservoir pressure dropped suddenly in addition to an early decline in oil production rate. These indicate a weak aquifer thus a need to inculcate a pressure maintenance operation in the field development 
Fig. 7 a Effect of pressure on oil viscosity. b Effect of pressure on oil formation volume factor. c Effect of pressure on solution gas oil ratio
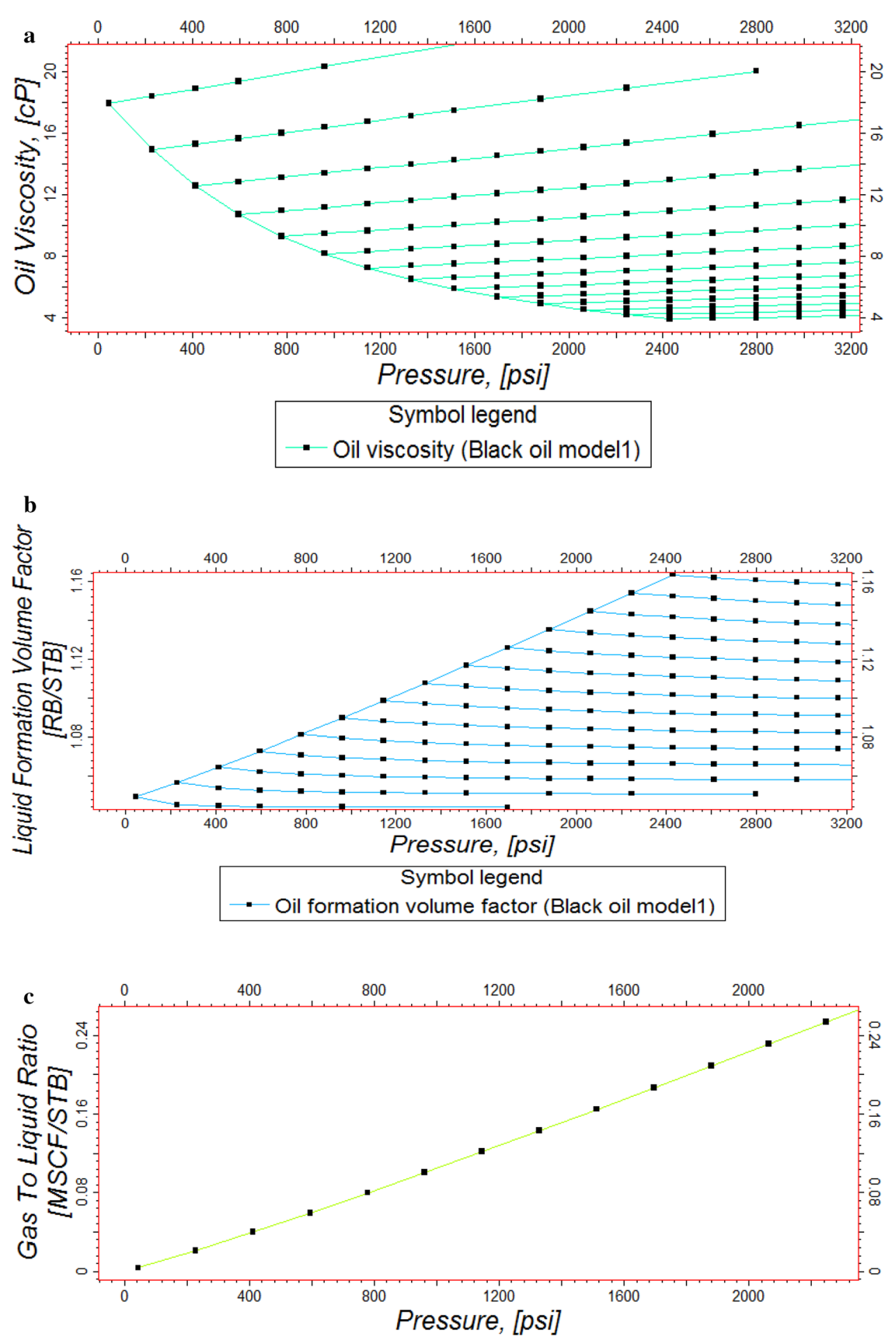

Symbol legend

Solution gas-oil ratio (Black oil model1) 
Table 2 Results from production prediction with natural depletion for 20 years

\begin{tabular}{ll}
\hline Reservoir Parameters & Values \\
\hline STOIP & $265.37 \mathrm{MMSTB}$ \\
Cumulative oil production after 20 years & $35.2 \mathrm{MMSTB}$ \\
Recovery Factor & $13.26 \%$ \\
Pressure drop after 20 years & $-380.45 \mathrm{psi}$ \\
Water cut & $70 \%$ \\
Gas Oil Ratio & $0.5 \mathrm{Mscf} / \mathrm{STB}$ \\
Water breakthrough time & 1 year \\
\hline
\end{tabular}

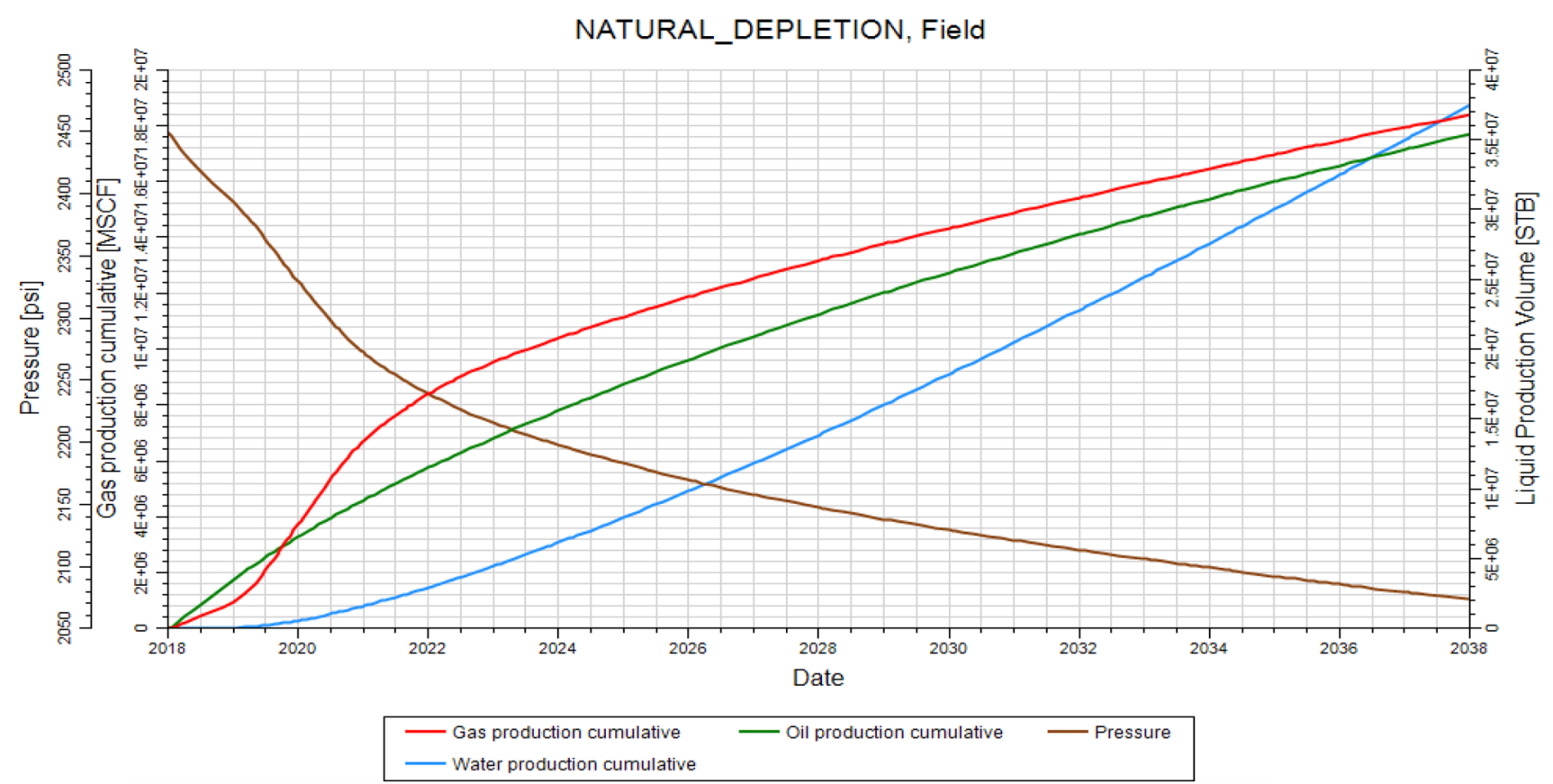

Fig. 8 Reservoir production performance plot at natural depletion

plan. The reservoir is saturated with a poor oil recovery factor of $13.2 \%$ in 20 years thus the pressure maintenance operation is to be started from the beginning of production to avoid increase in oil viscosity which will lead to lift problems and reduce oil sweep efficiency.

Figure 9 shows the well performance. Pressure dropped suddenly in all the wells confirming a weak aquifer drive. Well LSBU_V03 had the earliest water breakthrough time and earliest decline in oil production rate. Water production in all wells increased abruptly after water breakthrough causing a sharp decline in oil production rate.

Figure 10 shows a poor oil sweep, characteristics of high viscous oil, thus a pressure maintenance operation will not aid the sweep of the crude compared to a secondary recovery method. Waterflooding was selected instead of gas flooding, because the reservoir is saturated in addition to availability of water from the produced water. 
Fig. 9 a Well production performance plot at natural depletion. b Well production performance plot at natural depletion. c Well production performance plot at natural depletion. $\mathbf{d}$ Well production performance plot at natural depletion. Before natural depletion after natural depletion
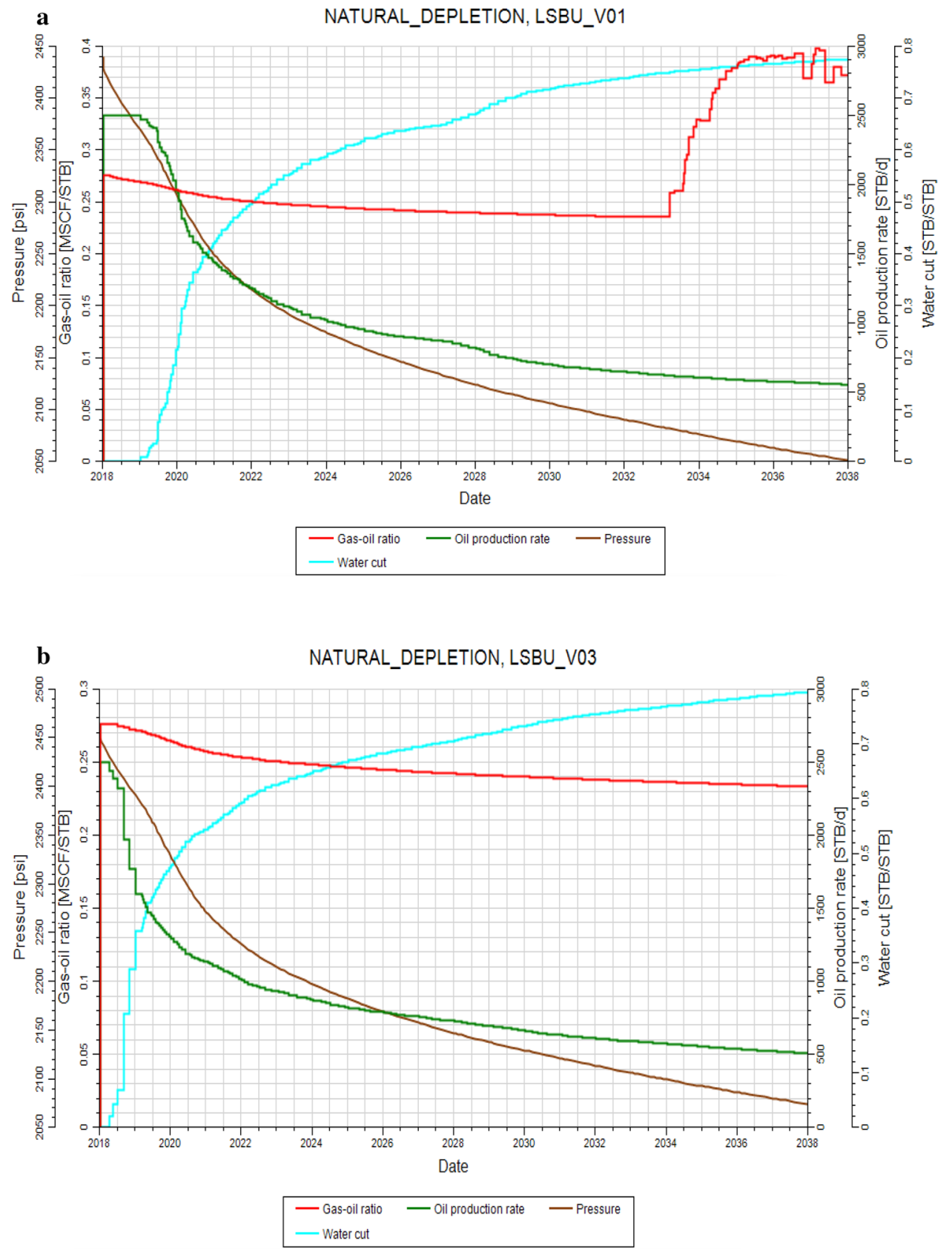
Fig. 9 (continued)
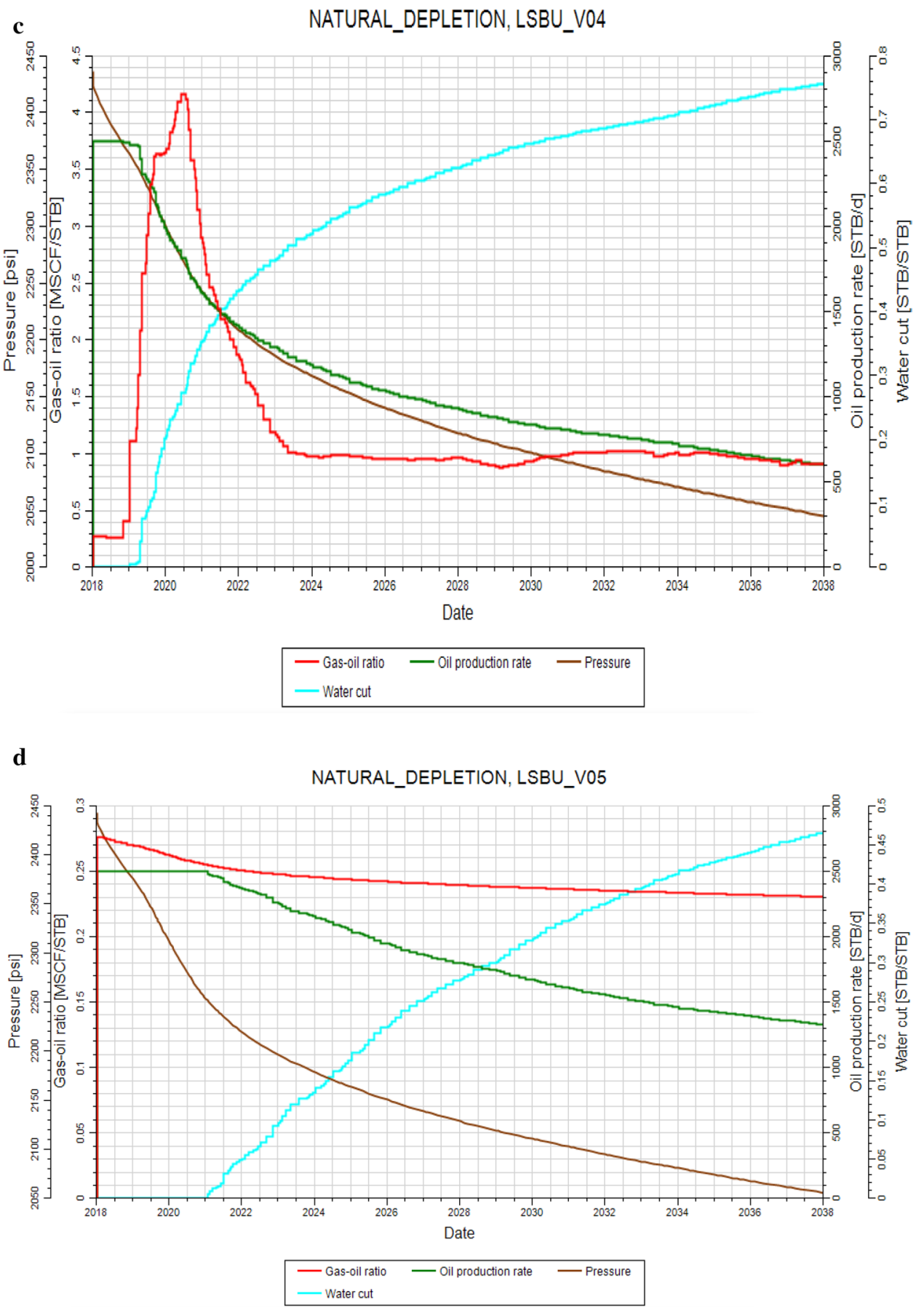


\section{Before natural depletion}

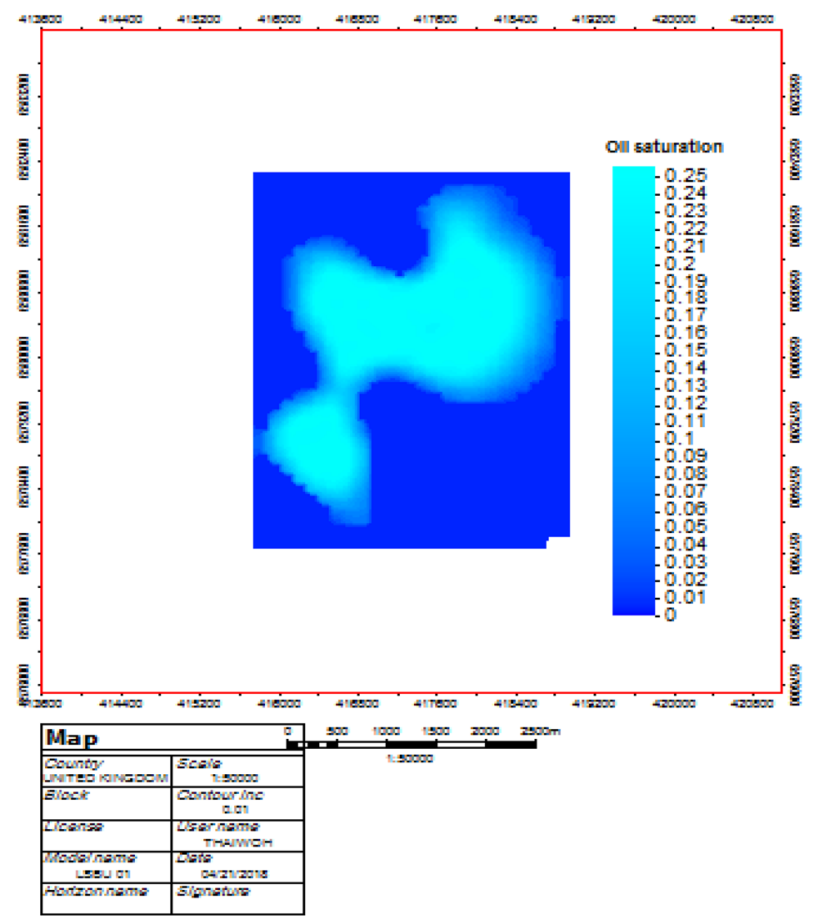

Fig. 10 Area map showing area sweep efficiency

\section{Depletion with waterflooding}

The reservoir was depleted for 25 years with waterflooding operation (Fig. 11). Irregular water flood pattern was chosen, because the existing well positions are irregular in addition to a highly irregular reservoir shape. Three different cases were proposed and analysed.

Case 1 Drilling two more producers and an injector. Thus the total number of wells is seven (6 producers and 1 injector) (Table 3 ).

Case 2 Drilling two more producers and an injector with conversion of well LSBU_V04 to an injector. Thus the total number of wells is seven ( 5 producers and 2 injectors)

(Table 3).

\section{After natural depletion}

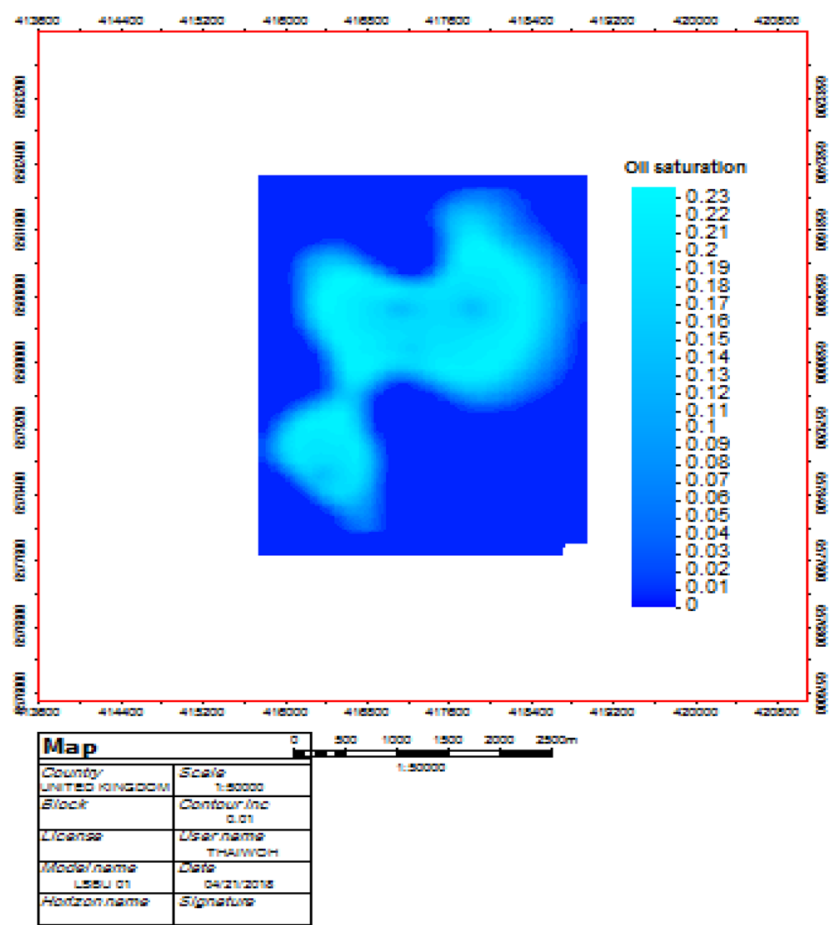

Case 3 Drilling three more producers and injectors with conversion of well LSBU_V04 to an injector. Thus total number of wells is eight (6 producers and 2 injectors).

Waterflooding the reservoir increased recovery from the reservoir though with a very high water cut. Case 1 increased recovery compared to natural depletion but there was still a very sharp decline in reservoir pressure indicating the need for more injectors. Case 3 gave the highest recovery with a very low GOR and a fair reservoir pressure maintenance, while case 2 resulted in a good recovery with a very low GOR and the best reservoir pressure maintenance compared with all cases. 
Fig. 11 a Reservoir production performance for waterflooding. b Reservoir production performance for waterflooding. c Reservoir production performance for waterflooding. d Reservoir production performance for waterflooding
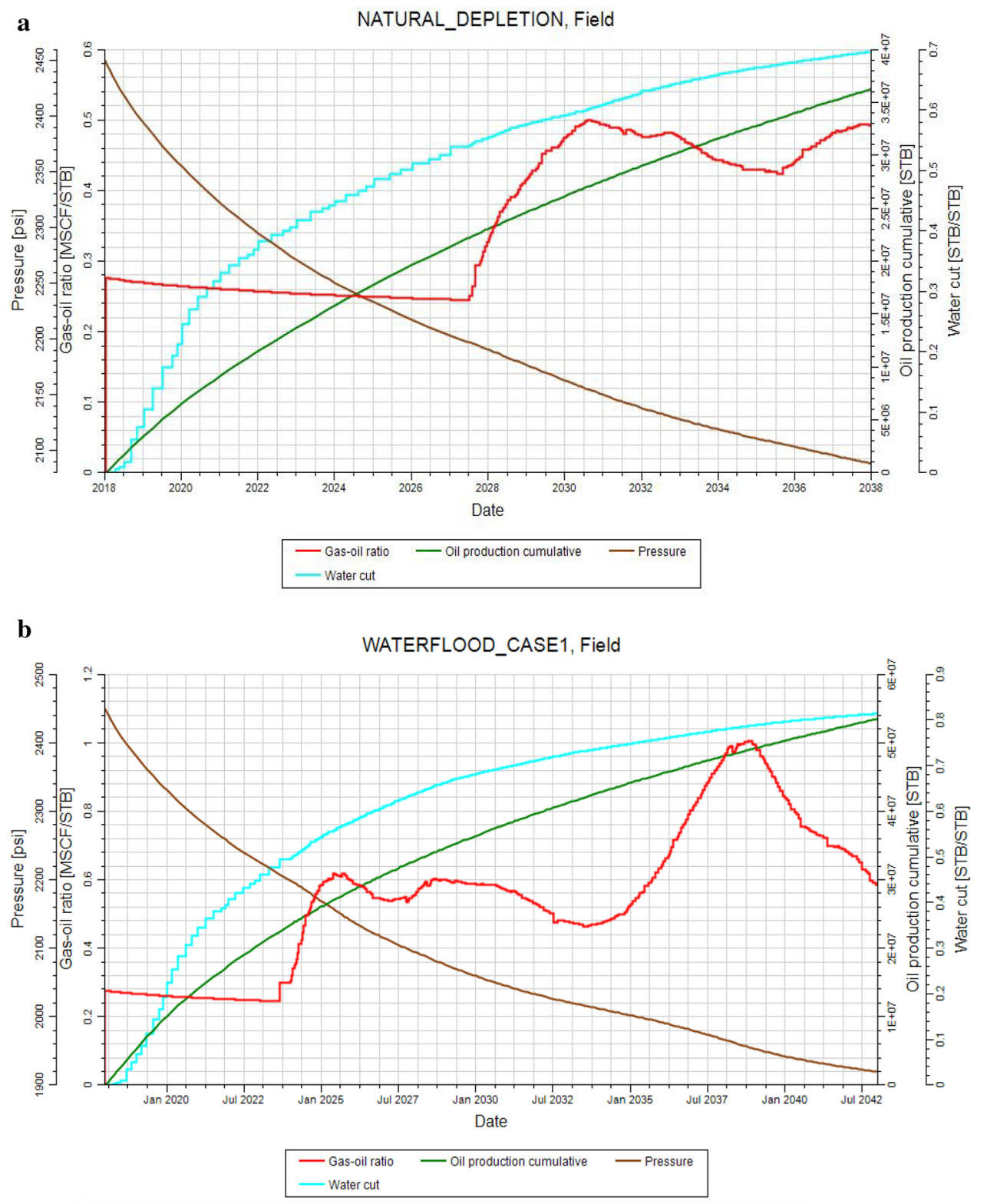
Fig. 11 (continued)
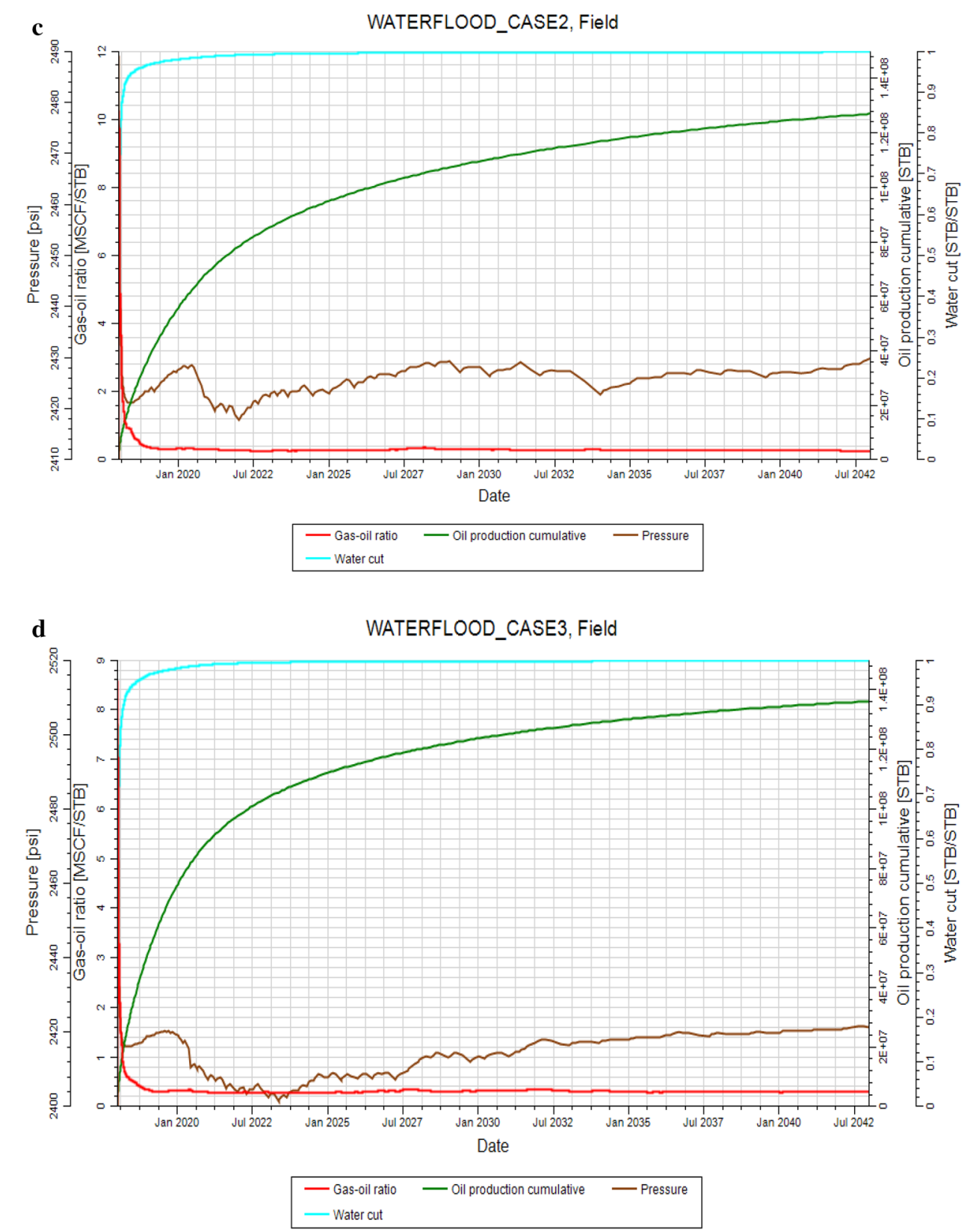

Table 3 Results from Production Prediction with Waterflooding for 25 Years

\begin{tabular}{llll}
\hline Reservoir Parameters & Case 1 & Case 2 & Case 3 \\
\hline STOIP & $265.37 \mathrm{MMSTB}$ & $265.37 \mathrm{MMSTB}$ & $265.37 \mathrm{MMSTB}$ \\
$\begin{array}{l}\text { Cumulative oil production after } \\
\quad 5 \text { years }\end{array}$ & $54.1 \mathrm{MMSTB}$ & $127 \mathrm{MMSTB}$ & $140 \mathrm{MMSTB}$ \\
Recovery factor & $20.39 \%$ & & \\
Pressure drop after 25 years & $-530.45 \mathrm{psi}$ & $-21.55 \mathrm{psia}$ & $-32.76 \%$ \\
Water cut & $80 \%$ & $99 \%$ & $99 \%$ \\
Gas Oil Ratio & $0.58 \mathrm{Mscf} / \mathrm{STB}$ & $0.4 \mathrm{Mscf} / \mathrm{STB}$ & $0.3 \mathrm{Mscf} / \mathrm{STB}$ \\
\hline
\end{tabular}




\section{Economic and sensitivity analyses}

\section{Basic economic concepts}

Cash flow of a project is the net cash generated or expended on the project as a function of time. The time value of money is included in economic analyses by applying a discount rate to adjust the value of money to the value during a base year. Discount rate is the adjustment factor, and the resulting cash flow is called the discounted cash flow. In this project, two investment appraisal tools where used for the economic analysis. These are Net present value (NPV) and Internal rate of return (IRR).

\section{Net present value}

Net present value (NPV) of the cash flow is the value of the cash flow at a specified discount rate. It's obtained as the summation of all the present values of the entire cash flow incurred by the project. It serves as the measure of project net worth. This is expressed mathematically as;

$\mathrm{NPV}^{\mathrm{cr}}=\sum_{t=1}^{k} \frac{\mathrm{NCF}_{t}^{\mathrm{cr}}}{(1+i)^{t}} 1$

where $\mathrm{NPV}^{\mathrm{cr}}=$ contractor net present value, $\mathrm{NCF}_{t}^{\mathrm{cr}}=$ net cashflow at year $t, i=$ interest rate, $t=$ time in years.

\section{Internal rate of return}

The discount rate at which NPV is zero is called the discounted cash flow return on investment (DCFROI) or Internal rate of return (IRR). Its important investment appraisal tool that measures the average annual income expected to be generated from the project. It's given mathematically as;

$N P V^{c r}=\sum_{t=1}^{k} \frac{N C F_{t}^{c r}}{(1+i)^{t}} 1$

Where IRR $=$ internal rate of return.

Below table stated the investment decision rule for NPV and IRR (Table 4).

Table 4 Investment Decision Rule

\begin{tabular}{lll}
\hline Indicators & Accept & Reject \\
\hline Net present value & $\mathrm{Npv}>0$ & $\mathrm{Npv}<0$ \\
Internal rate of return & $\mathrm{IRR}>\mathrm{r}$ & $\mathrm{IRR}<\mathrm{r}=$ discount rate \\
\hline
\end{tabular}

\section{Cash flow modelling}

The cash-flow model was built using Microsoft Office Excel. The goal is to obtain the NPV and IRR for the development of the field. The cash flow of the development is simply the cash expanded over a defined period. The process of obtaining the cash flow starts with obtaining a production profile. From this, the revenue generated yearly is obtained and the cash spent yearly is also obtained. The cash received less cash spent is the Net Cash Flow.

\section{Gross revenue}

This is the amount of income generated per year on the sales of crude oil by the field operator. It is given as;

Gross revenue per year (price escalating by $2 \%$ each year for this project $)=($ Annual oil production $\times$ Oil price $)+$ (Annual gas production $\times$ gas price.

\section{Costs (capex and opex)}

The two major costs associated with developing any type of oil fields are the Capital Expenditures (Capex) and Operating Expenditure (Opex).

\section{CAPEX}

These are capital intensive investments which are needed to exploit and produce oil. CAPEX spent in developing the field include geological and geophysical (G\&G) costs, exploratory, appraisal, and development (infill) drilling costs, side tracking, workovers, surface/processing facilities, pipeline laying, preventive maintenance of production facilities and infrastructures, etc.

\section{OPEX}

This is operating expenditure and refers to the money required to operate and maintain the facilities, to lift the oil and gas to the surface; and to gather, treat and transport hydrocarbons. These costs are usually direct costs that are spent to run the operational activities of marginal fields which include production, processing and transportation cost. General and administrative cost is also an operating expenditure. Usually overheads take a huge chunk of OPEX. OPEX can either be fixed or variable cost. In this work fixed cost was used for OPEX.

In this research the cash flow models were successfully developed for all the 4 cases considered: natural depletion, waterflood case 1 , waterflood case2, waterflood case 3 . The results for their respective NPV's are $\$ 275,120,228$, $\$ 392,353,022, \$ 2,163,756,338, \$ 1,904,051,958$, while their internal rate of returns are: $30 \%, 35 \%, 47 \%$ and $38 \%$. All the cases show that the investment at the four cases is profitable, 
since the NPV is greater than zero and the investment returns are also greater than the discount rate.

\section{Sensitivity analysis}

\section{Chart 1: Natural depletion: impact of parameters on NPV}

\begin{tabular}{llll}
\hline & \multicolumn{2}{l}{ Sensitivity analysis for NPV(\$) } & \\
& $-10 \%$ & Base value & $10 \%$ \\
\hline Oil price & $138,480,655$ & $275,120,228$ & $411,759,801$ \\
Gas price & $272,422,792$ & $275,120,228$ & $277,817,664$ \\
Prod rate & $251,330,495$ & $275,120,228$ & $298,909,960$ \\
Capex & $312,250,778$ & $275,120,228$ & $237,989,678$ \\
Opex & $349,814,664$ & $275,120,228$ & $200,425,791$ \\
\hline
\end{tabular}

Opex $\{-10 \%$ to $+10 \%\}$

Capex $\{-10 \%$ to $+10 \%\}$

Prod rate $\{-10 \%$ to $+10 \%\}$

Gas price $\{-10 \%$ to $+10 \%\}$

Oil price $\{-10 \%$ to $+10 \%\}$

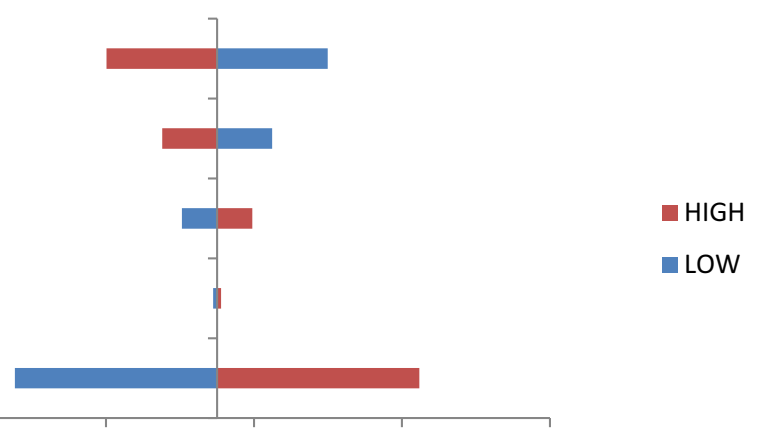

\section{Chart 2: Waterfloodingcase1}

\begin{tabular}{llll}
\hline & & \multicolumn{2}{l}{ Sensitivity analysis for NPV(\$) } \\
\cline { 3 - 4 } & $-10 \%$ & Base value & $10 \%$ \\
\hline Oil price & $197,007,162$ & $392,353,022$ & $587,698,883$ \\
Gas price & $387,565,033$ & $392,353,022$ & $397,141,011$ \\
Prod rate & $356,316,192$ & $392,353,022$ & $428,389,853$ \\
Opex & $502,156,970$ & $392,353,022$ & $282,549,075$ \\
Capex & $443,447,622$ & $392,353,022$ & $377,258,422$ \\
\hline
\end{tabular}

Capex $\{-10 \%$ to $10 \%\}$

Opex $\{-10 \%$ to $10 \%\}$

Prod rate $\{-10 \%$ to $10 \%\}$

Gas price $\{-10 \%$ to $10 \%\}$

Oil price $\{-10 \%$ to $10 \%\}$

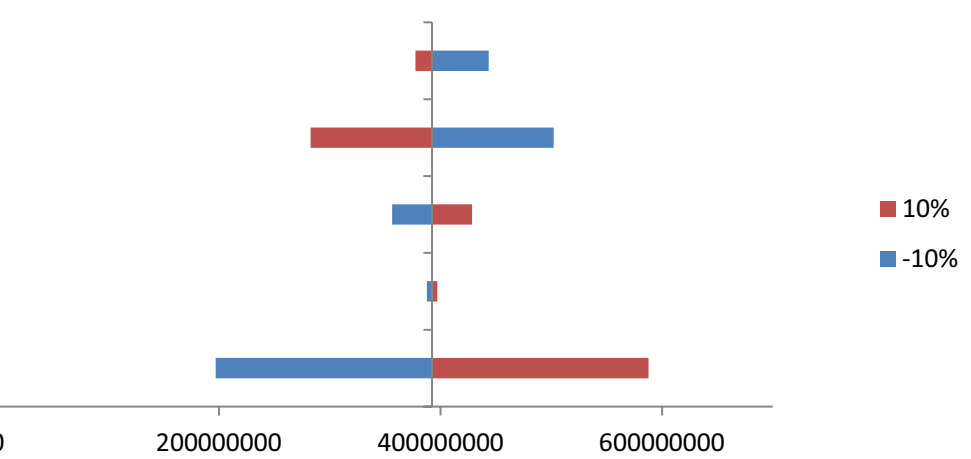




\section{Chat 3: Waterfloodingcase2}

\begin{tabular}{llll}
\hline & & \multicolumn{2}{l}{ Sensitivity analysis for NPV $(\$)$} \\
\cline { 3 - 4 } & $-10 \%$ & Base value & $10 \%$ \\
\hline Oil price & $1,538,461,632$ & $2,163,756,338$ & $2,789,051,043$ \\
Gas price & $2,163,756,333$ & $2,163,756,338$ & $2,163,756,342$ \\
Prod rate & $2,155,993,489$ & $2,163,756,338$ & $2,171,519,186$ \\
Opex & $2,281,403,424$ & $2,163,756,338$ & $2,046,109,251$ \\
Capex & $2,464,281,978$ & $2,163,756,338$ & $1,863,230,697$ \\
\hline
\end{tabular}

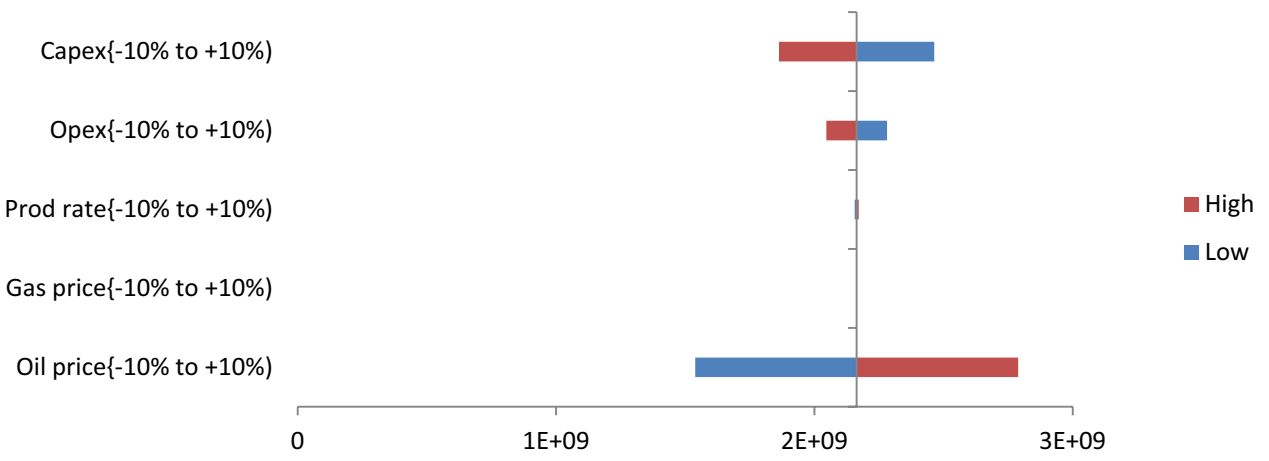

\section{Chart 4: Water floodingcase 3}

\begin{tabular}{llll}
\hline & \multicolumn{2}{l}{ Sensitivity analysis for NPV(\$) } & \multirow{2}{l}{$10 \%$} \\
\cline { 2 - 3 } & $-10 \%$ & Base value & $2,630,097,923$ \\
Oil price & $1,178,005,993$ & $1,904,051,958$ & $1,952,590,850$ \\
Gas price & $1,855,513,066$ & $1,904,051,958$ & $2,249,031,869$ \\
Prod rate & $1,559,072,047$ & $1,904,051,958$ & $1,778,561,732$ \\
Opex & $2,029,542,184$ & $1,904,051,958$ & $1,462,326,808$ \\
Capex & $2,345,777,108$ & $1,904,051,958$ & \\
\hline
\end{tabular}

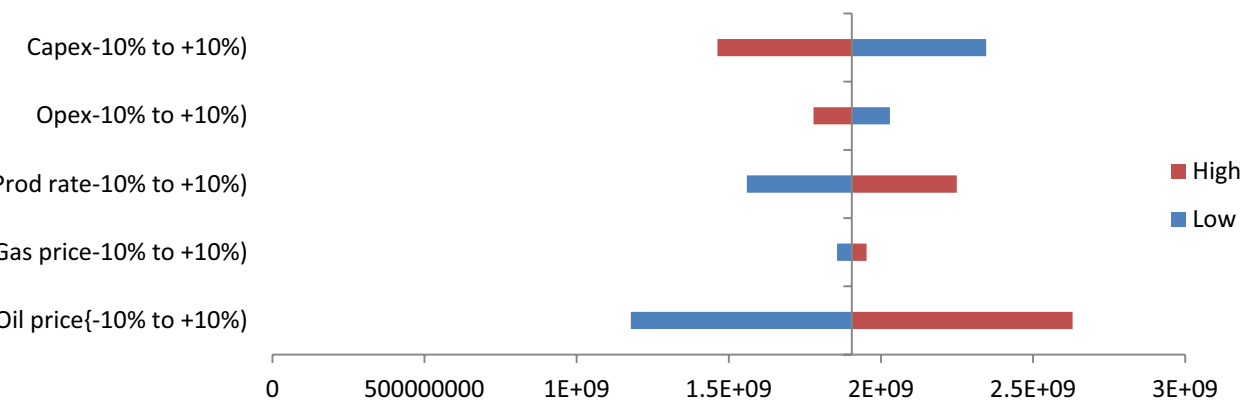


Tornado chart usually gives the oil firm a snapchat of the variable(s) to concentrate on more, so as to minimize the risk inherent in the project. When the oil and gas field was subjected to one-way sensitivity analysis, the results revealed that the oil price and the Opex have the greatest impacts on the field in natural depletion and case 1 . While the oil price and the capex are the most influencial factors in case 2 and case 3 . Also the changes in the gas price have a minor effect on the field NPV in all the cases been considered.

\section{Conclusion}

A fit for purpose geological model of the reservoir was constructed using a simple 3D grid. Geological cells into which the petrophysical properties were populated were generated via the 3D simple grid. Petrophysical properties were then populated into these cells using the conceptual variogram analysis, Sequential Gaussian Random Function, existing relationships and petrel calculator.

Dynamic Simulation was then run on the static model. Existing wells were completed and development strategies on how to improve the recovery either by drilling new wells or converting existing wells into injectors were made.

A good field development plan integrates an in depth reservoir study and economic analysis tool. Thus, it involves a team of geologists, petrophysists, geophysists, well engineers, reservoir engineers, production engineers and economists.
Waterflooding increases recovery from the reservoir as can be seen the case study.

Open Access This article is distributed under the terms of the Creative Commons Attribution 4.0 International License (http://creativeco mmons.org/licenses/by/4.0/), which permits unrestricted use, distribution, and reproduction in any medium, provided you give appropriate credit to the original author(s) and the source, provide a link to the Creative Commons license, and indicate if changes were made.

\section{References}

Ahmed T (1989) Hydrocarbon Phase Behavior. Gulf Publishing Company, Houston

Ahmed T (2010) Reservoir Engineering Handbook (4th ed.). Gulf Professional Publishing

Al-Marhoun MA (1985) Pressure-Volume-Temperature Correlations for Saudi Crude Oils

Cosentino L (2001) Integrated Reservoir Studies. InstitutFrancais Du Petrole Publications

Dake LP (1996) Fundamentals of Reservoir Engineering. Sara Burgerhartstraat 25

Danesh A (1998) PVT and Phase Behavior of Petroleum Reservoir Fluid. Elsevier Science

Glaso O (1980) Generalized Pressure-Volume-Temperature Correlations. Journal of

Publisher's Note Springer Nature remains neutral with regard to jurisdictional claims in published maps and institutional affiliations. 